\title{
Diastereoselective Synthesis of Nitropyrrolizidines from Enantiopure exo-4- Nitro-3,5-diphenylproline through 1,3-Dipolar Cycloadditions of non- Stabilized Azomethine Ylides
}

\author{
Eduardo García-Mingüens ${ }^{a, b}$, Carmen Nájera*a and José M. Sansano*a,b \\ a Departamento de Química Orgánica and Centro de Innovación en Química Avanzada (ORFEO-CINQA). Facultad de \\ Ciencias, Universidad de Alicante, 03080-Alicante, Spain; ${ }^{b}$ Instituto de Síntesis Orgánica (ISO). Facultad de Ciencias, \\ Universidad de Alicante, 03080-Alicante, Spain.
}

\section{Dedicated to Prof. Miguel Yus on the occasion of his 70th birthday and for his contribution as Editor-in-Chief of Letters in Organic Chemistry}

\begin{abstract}
Enantiopure exo-4-nitro-3,5-diphenylproline reacts with aldehydes and electrophilic alkenes, in good yields, through a multicomponent 1,3-dipolar cycloaddition where the intermediate azomethine ylide is generated by the decarboxylative route. The reactions with maleimides afford diastereoselectively nitropyrrolizidines. Dimethyl fumarate and 1,2-bis(phenylsulfonyl)ethylene also give variable mixtures of diastereoisomeric nitropyrrolizidines. The replacement of aldehydes by phenyl-3-buten-2-one also affords satisfactory results with high diastereoselection although in lower yields. The stereochemical outcome is studied and defined according to the absolute configuration of the resulting cycloadducts.
\end{abstract}

Keywords: pyrrolizidine · nitroprolinates · cycloaddition · azomethine ylides · decarboxylation · multicomponent.

\section{INTRODUCTION}

Pyrrolizidine alkaloids (PAs) constitute one of the most attractive families of natural products [1] due to their wide and diverse set of biological applications. However, hepatotoxicity, especially veno-occlusive disease, is the most serious result of ingestion of PAs [2,3]. On the other hand, PAs are not all toxic and the range of potential activity is very promising in many scientific areas [4]. Although the most abundant are hydroxylated PAs, non-hydroxylated natural pyrrolizidines shown in Figure 1 also exhibit potent glycosidase inhibition apart from other biological properties [5].

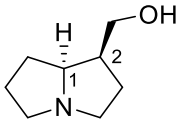

(-)-Isoretronecanol

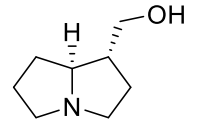

(-)-Trachelantamidine

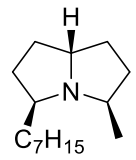

(+)-Xenovenine

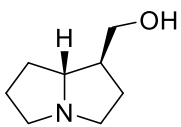

$(+)$-Laburnine
Figure 1. Non hydroxylated naturally occurring PAs.

* Departamento de Química Orgánica and Centro de Innovación en Química Avanzada (ORFEO-CINQA). Facultad de Ciencias, Universidad de Alicante, Apdo- 99, 03080-Alicante, Spain; E-mails: cnajera@ua.es and jmsansano@ua.es
There are several approaches to the synthesis of these alkaloids $[1,6]$ but the most straightforward route consists in the employment of 1,3-dipolar cycloaddition (1,3-DC) of alkenes and stabilized azomethine ylides generated from prolinates, following the typical iminium route (Scheme 1 , eq. a) $[7,8]$, or even following a generation of non-stabilized azomethine ylide through a decarboxylative route employing proline (Scheme 1, eq. b and c). This last route allowed the synthesis of complex skeletons when proline and isatine were involved in the process [9] In this sense, Felluga et al. also described a three component decarboxylative diastereoselective 1,3-DC version using (2S,4R)-4hydroxyproline and 2,3-butanedione or ethyl pyruvate with $\beta$-nitrostyrene to give, at room temperature, mixtures of diastereomeric pyrrolidines in good yields (78-90\%) (Scheme 1 , eq. c). [10] 
(eq. a)

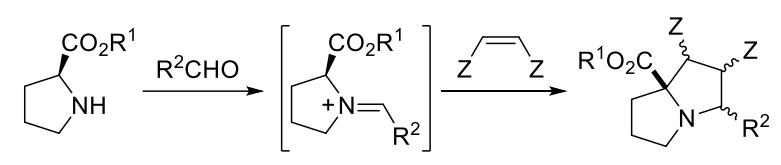

(eq. b)

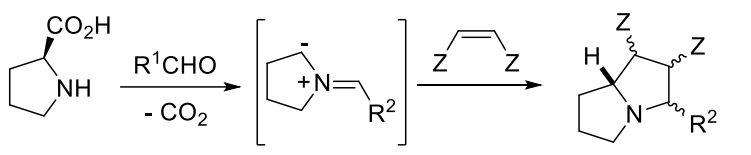

(eq. c)

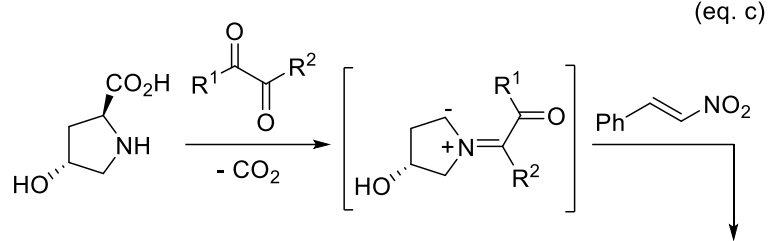<smiles>[R]C(=O)[C@]1([R1])[C@@H]([N+](=O)[O-])[C@@H](c2ccccc2)[C@@H]2C[C@H](O)CN21</smiles>

Scheme 1. Pyrrolizidine synthesis from azomethine ylides generated by the iminium route or by decarboxylation of proline derivatives.

To the best of our knowledge, this is the sole publication in which a chiral proline derivative was employed for the preparation of pyrrolizidines. So, according to our experience in the preparation of enantiomerically enriched pyrrolizidines, following the route depicted in eq. a) of Scheme 1 from enantiomerically enriched prolinates [7c], we decided to study the diastereoselective multicomponent decaboxylative 1,3-DC using enantiomerically pure nitroprolinate exo-1, aldehydes or ketones and electrophilic alkenes. So, the synthesis of polysubstituted nonhydroxylated pyrrolizidines will be surveyed.<smiles>O=C(O)C1NC(c2ccccc2)C(C(=O)O)C1c1ccccc1</smiles>

The selection of this starting pyrrolidine 1 bearing a nitro group [11] is due to the recent importance of nitroprolinates as useful tools in organic synthesis as organocatalysts $[12,13,14]$, chiral ligands $[12,15,16]$, and chiral building blocks [17,18]. Their biological properties are very interesting: for example, it was found a family of inhibitors of $\alpha_{4}, \beta_{1}$-integrin-mediated hepatic melanoma and in a murine model of colon carcinoma metastasis, as well as potent antiadhesive properties in several cancer cell lines $[19,20]$. Several compounds acted as inhibitors of skin cancer [21], they can increase the mortality of zebrafish embryos [22], and a series of nitroprolinates were successfully tested as antimycobacterials against $M$. tuberculosis H37Rv strain $[23,24,25]$. Besides, the nitro group can be easily transformed in several functional groups and it has been found as the responsible atomic arrangement of stereodivergent cycloaddition processes [18].

\section{RESULTS AND DISCUSSION}

Enantioenriched methyl 4-nitro-3,5-diphenylprolinate (exo-2), prepared by enantioselective catalytic 1,3-DC of methyl benzylideneglycinate with $\beta$-nitrostyrene, in the presence of a chiral phosphoramidite.AgOBz complex (5 mol\%) in >99:1 er (>99:1 exo:endo dr) [26,27], was allowed to react through a hydrolytic process (Scheme 2). Proline derivative exo-1 was obtained in $85 \%$ yield by treatment with sodium hydroxide in a 1:1 water:acetone [14] solution at room temperature during $16 \mathrm{~h}$.

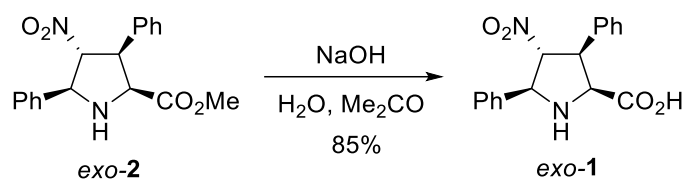

Scheme 2. Synthesis of proline derivative exo-1.

Next, the multicomponent 1,3-DC between nitroproline exo-1, cinnamaldehyde and $\mathrm{N}$-methylmaleimide (NMM) was studied (Scheme 3, Table 1). Toluene was selected as solvent because it was the most appropriate in previous articles regarding [3+2] [7b,c] or [4+2] [18] cycloadditions involving prolinates. Temperature was the main parameter to be implemented for achieving the maximum conversion. The decarboxylation of the iminium salt formed between exo-1 and cinnamaldehyde occurred at room temperature as well as the successive cycloaddition with NMM (Table 1, entry 1). In this case, a mixture of diastereoisomers endo-3a:endo-4a was obtained in 40:60 ratio and in excellent $90 \%$ overall yield. The conversions of this reaction decreased when lower temperatures $\left(10{ }^{\circ} \mathrm{C}\right.$ or $\left.0{ }^{\circ} \mathrm{C}\right)$ were assayed. $\mathrm{N}$ Phenylmaleimide (NPM) was tested under the same reaction conditions affording a 1:1 mixture of inseparable endo-3b and endo-4b adducts in $81 \%$ overall yield (Table 1 , entry 2 ). However, when $\mathrm{N}$-(5-bromophenyl)maleimide was used a total diastereoselection was observed after analyzing the ${ }^{1} \mathrm{H}$ NMR spectra of the crude material. Product endo-3c was isolated in $80 \%$ yield (Table 1 , entry 3 ).

Dimethyl fumarate was found to be an appropriate dipolarophile because total diastereoselection was observed giving endo-3d. The temperature of the multicomponent sequence was $25^{\circ} \mathrm{C}$ as well, in short reaction time $(6 \mathrm{~h})$ and in good $76 \%$ yield (Table 1, entry 4 ). A similar chemical yield was achieved when 1,2-bis(phenylsulfonyl)ethylene (BPSE) was employed as dipolarophile under the same reaction conditions, but the diastereoselection was lower obtaining an 70:30 mixture of presumed endo-3e:endo-4e and endo-3e could be isolated in $50 \%$ yield allowing the configuration assignment (Table 1, entry 5).

When other aldehydes, different to cinnamaldehyde, were studied, namely benzaldehyde or dihydrocinnamaldehyde, longer reaction time $(17 \mathrm{~h})$ and higher temperature $\left(70{ }^{\circ} \mathrm{C}\right)$ were needed. The diastereoselection of the reaction with different dipolarophiles regarding benzaldehyde and dimethyl 
fumarate was very low obtaining a 66:34 endo-3f:endo-4f ratio in $84 \%$ overall yield (Table 1 , entry 6 ). In both examples performed with dihydrocinnamaldehyde 65:35, inseparable mixture of the corresponding products endo-3g:endo-4g and endo-3h:endo-4h were isolated in $23 \%$ and $26 \%$ overall yields, respectively (Table 1 , entries 7 and 8 ).

4-Phenyl-3-buten-2-one also formed a reactive azomethine ylide after decarboxylation, ready to react with NMM and dimethyl fumarate (Table 1, entries 9 and 10). The highest both diastereoselection and chemical yield was obtained with NMM (only endo-3i was isolated, $47 \%$ yield) meanwhile dimethyl fumarate furnished an unpurified pyrrolizidine endo-3j in $30 \%$ yield.
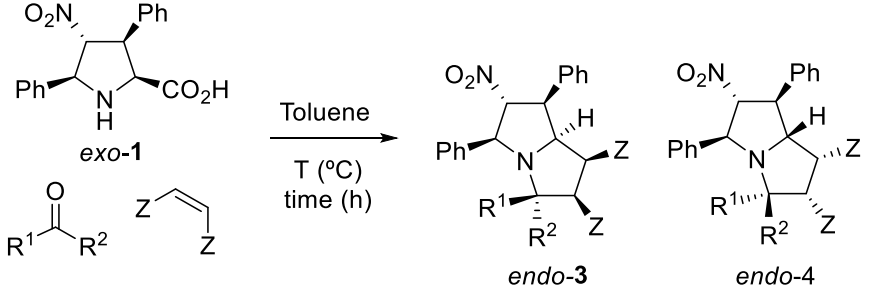

Scheme 3. Multicomponent diastereoselective 1,3-DC with exo-1, aldehydes/ketones and dipolarophiles.

Table 1. Synthesis of nitropyrrolizidines endo-3 and endo-4.

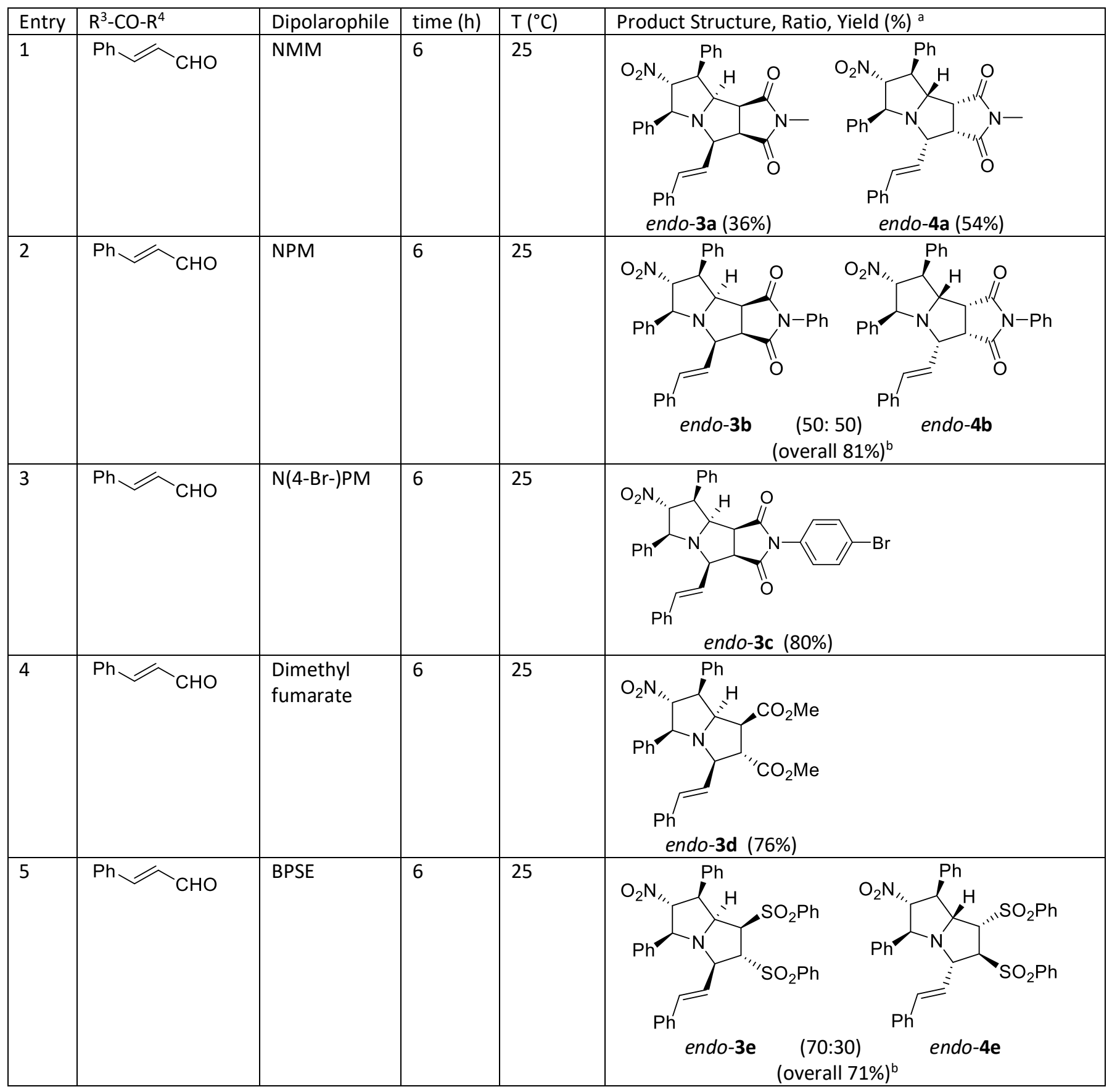




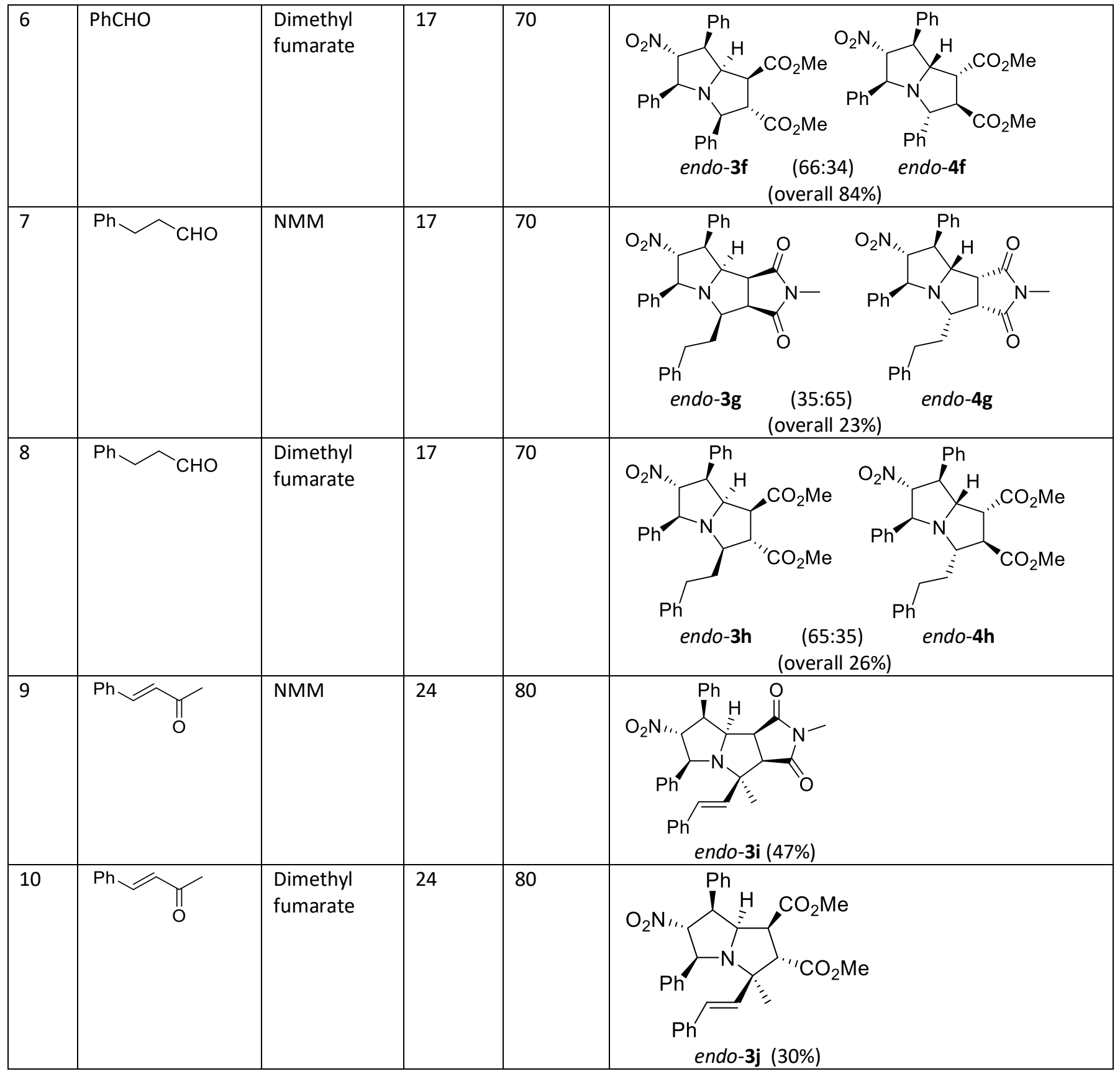

${ }^{a}$ Isolated yield after flash chromatography.

${ }^{\mathrm{b}}$ Compound endo-3e was isolated in $50 \%$ yield.

According to several NMR bidimensional experiments, especially NOESY and individual signal irradiations (Figure 2), the represented structures of the Table 1 were assigned. In the examples performed with NMM the two observed diastereoisomers could be separated. The endo-4a shown nOe between $\mathrm{H}(4)-\mathrm{H}(5)$ and $\mathrm{H}(6)-\mathrm{H}(7)$ but any increment of residual population was detected between $\mathrm{H}(3)-\mathrm{H}(4)$ unlike to the very intense nOe observed in the case of product endo3a. In this last molecule, nOe of $\mathrm{H}(4)-\mathrm{H}(5)$ and $\mathrm{H}(6)-\mathrm{H}(7)$ were also representative. In the reaction dealing with cinnamaldehyde and dimethyl fumarate the resulting pure cycloadduct endo-3d showed very intense nOe $\mathrm{H}(3)-\mathrm{H}(4)$, $\mathrm{H}(4)-\mathrm{H}(5)$ and $\mathrm{H}(5)-\mathrm{H}(7)$ and a significant negative nOe $\mathrm{H}(6)-$
$H(7)$ (see, supporting information for the analysis of NMR experiments of the other molecules). 


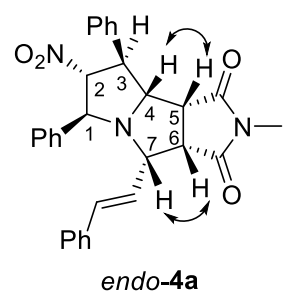
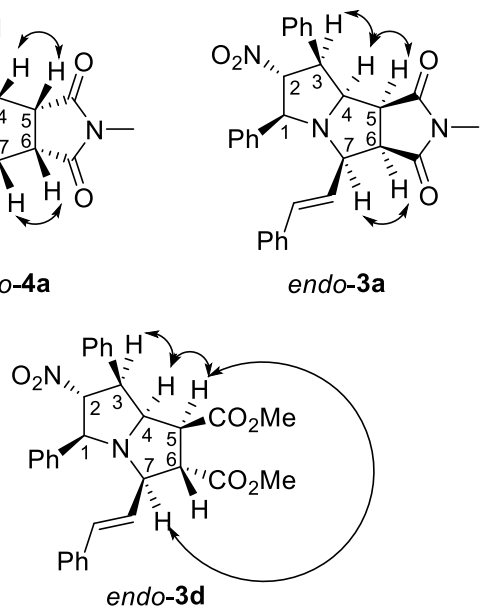

Figure 2. Most representative nOe in molecules endo-4a, endo-3a and endo-3d.

With all these data in hand, the absolute configuration of the resulting compounds revealed that two possible endoapproaches towards dipole $\mathbf{I}$ are the responsible of the reaction course, that means, the endo up and the endo down afforded cycloadducts endo-3 and endo-4, respectively. For the example of NMM, the major diastereoisomer endo-4a corresponded to the endo down reaction pathway (Scheme 4). Analyzing our previous experience with the stabilized azomethine ylide II, the major or exclusive endo ${ }_{\text {down }}$ approach occurred, through the less hindered part of the dipole [ $7 b c]$, but now the absence of the methoxycarbonyl group of the pyrrolidine ring facilitated the reaction by this upper face by the NMM eluding the stereoelectronic interaction with the nitro group. In cycloadduct endo-3a the ${ }^{1} \mathrm{H}$ NMR signal of the methyl group bonded to the nitrogen atom is shielded due to the proximity to the center of the aromatic electronic cloud (see the analogy with Figure 3 but anchoring a methyl group instead a phenyl substituent in the maleimide part). However, the methyl group in endo-4a is deshielded with respect to the corresponding one of the endo-3a around 0.5 ppm.

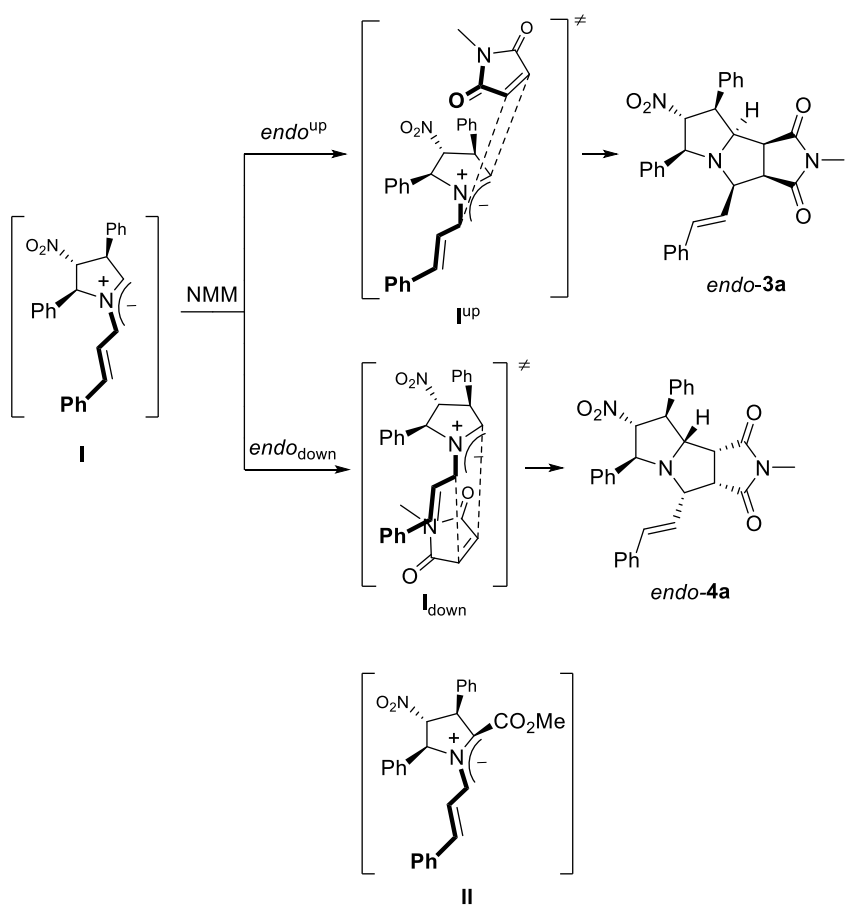

Scheme 4. Two possible endo approaches of NMM to the non-stabilized azomethine ylide $\mathbf{I}$.

The approach of the NMM to the corresponding dipoles generated by dihydrocinnamaldehyde followed the same trend obtaining endo-4g cycloadduct as major isomer. This idea was supported by the chemical shift observed for the methyl group bonded to the nitrogen atom (see above). With phenyl-3-buten-2-one, the nature of the dipole is different and also it is much more hindered giving access to a unique diastereoisomer as a consequence of a endo ${ }^{\text {up }}$ attack.

However, when the substituent of the nitrogen atom of the maleimide is an aromatic group the diastereoselection is partially displaced to a 1:1 diastereomeric endo-3b:endo-4g, mixture in the example run in the presence of NPM, or totally displaced (only one diastereoisomer endo-3c was obtained) in the case of working with $\mathrm{N}$-(4-bromophenyl)maleimide. Using very simple calculations [28] the presence of these aromatic rings in maleimides favor a strong $\pi$-interaction between them and the phenyl ring allocated in $\mathrm{C}(3)$ and a very weak $\pi$-interaction with the phenyl group of the cinnamyl residue (Figure 3 ). It seems that the electronic inductive effect of the bromine atom increases the attraction of the two aryl moieties. The possible intense electronic repulsions of the nitro group with this bulkier maleimides is another important detail to remark. 


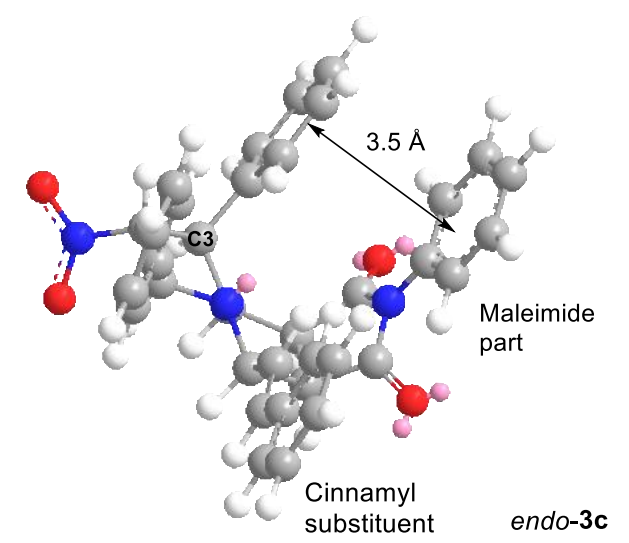

Figure 3. Possible $\pi$-interactions favoring the endo up approach for the reactions involving $N$-arylmaleimides.

When dimethyl fumarate was employed as dipolarophile, it was expected two possible endo-approaches as deduced for the behavior of NMM in Scheme 4. The exclusive diastereoisomer isolated and fully characterized endo-3d, indicated that the preference of the endo up pathway would be only possible (confirmed by nOe results depicted in Figure 2). The lower energy calculated for endo up approach also supports the presence of this unique diastereoisomer (Figure 4). These two combined data were also very interesting in order to clarify the exact position of the negative charge of the dipole $\mathbf{I}$, which triggers the Michael-type addition $\left(1^{\text {st }}\right.$ step) with simultaneous Mannich type reaction. This negative charge was better stabilized by the allylic system rather than in the inner part of the cycle matching with the stereochemical outcome observed. This model can be extended to other cycloadducts derived from dimethyl fumarate and also from BPSE.
$\mathrm{E}=31.207 \mathrm{kcal} \cdot \mathrm{mol}^{-1}$<smiles>COC(=O)[C@@H]1[C@H](c2ccccc2)[C@@H]2[C@@H](c3ccccc3)[C@@H]([N+](=O)[O-])[C@H](c3ccccc3)N2[C@@H]1C=Cc1ccccc1</smiles>

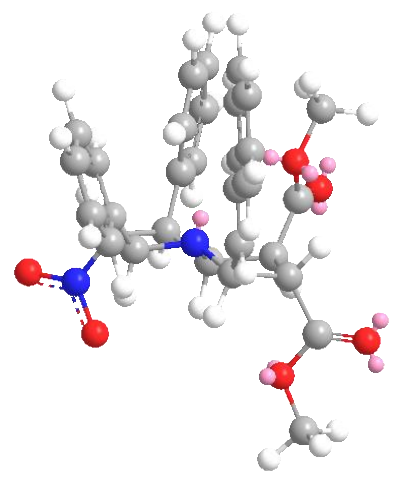

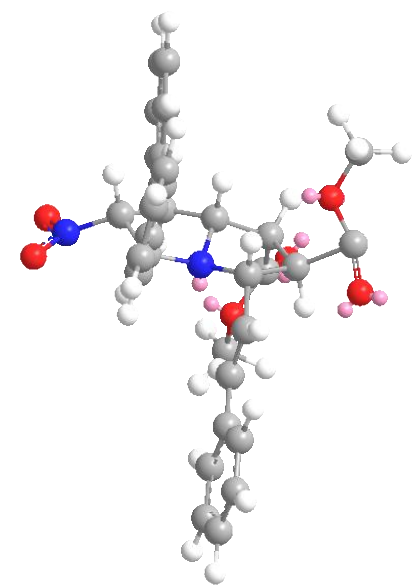

$E=128.578 \mathrm{kcal} \cdot \mathrm{mol}^{-1}$

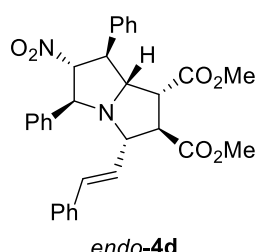<smiles>COC(=O)/C=C\C(=O)OC</smiles>

Figure 4. Minimun energy of endo-cycloadducts endo-3d and endo-4d and proposed geometry of the intermediate 1,3-dipole.

\section{EXPERIMENTAL SECTION}

\subsection{General}

\section{2. (2S,3S,4R,5S)-4-Nitro-3,5-diphenylpyrrolidine-2- carboxylic acid, exo-1 [14]}

To a suspension of the polisubstituted proline $(400 \mathrm{mg}, 1.23$ $\mathrm{mmol}$ ) in $5 \mathrm{~mL}$ of acetone was added dropwise sodium hydroxide ( $120 \mathrm{mg}, 3 \mathrm{mmol}$ ) in $5 \mathrm{~mL}$ of water. The resulting mixture was stirred for $16 \mathrm{~h}$. Then, the solution was cooled to $5{ }^{\circ} \mathrm{C}$ and treated with hydrochloric acid $2 \mathrm{M}$ to $\mathrm{pH} 2$ obtaining the desired product as a precipitate. After filtration and washing with water a yellow pale solid was afforded (326 $\mathrm{mg}, 1.04 \mathrm{mmol}) \cdot[\alpha]_{D}^{26}=82.1$ (c 1 , acetone), ${ }^{14}[\alpha]_{D}^{26}$ (exp.) = 61.4 (c 1, acetone); ${ }^{1} \mathbf{H}$ NMR (300 MHz, $\mathbf{C D C l}_{3}$ ): $\delta$ 4.54-4.66 (m, $\left.2 \mathrm{H}, \mathrm{NCHCO}_{2} \mathrm{H}, \mathrm{NCHCHPh}\right), 4.93$ (d, J = 8.6, NCHPh), 6.46 $\left(t, J=8.6, \mathrm{CHNO}_{2}\right)$ 7.28-7.68 (m, 10H, ArH) ppm.

\subsection{General procedure for the synthesis of pyrrolizidines} 3 and 4. 
To a suspension of the corresponding polisubstituted proline exo-1 (100 mg, $0.32 \mathrm{mmol})$ in toluene was added dropwise the corresponding aldehyde or ketone (1 equiv.). After 5 minutes was added the dipolarophile (1.1 equiv.) and the reaction mixture was checked by TLC (hexane:ethyl acetate, 8:2). The resultant solution was dried under vacuum and the crude residue was purified by column chromatography (hexane:ethyl acetate, 8:2). Time and temperatures of the different reaction are collected in the table.

\subsection{1 (3aR, $4 R, 6 S, 7 R, 8 S, 8 a S, 8 b S)$-2-Methyl-7-nitro-6,8-} diphenyl-4-((E)-styryl)hexahydropyrrolo[3,4-

a]pirrolizine-1,3(2H,8bH)-dione, endo-4a

White solid (hexane/ethyl acetate). Yield 54\%. Melting Point: $191-193^{\circ} \mathrm{C} ;[\alpha]_{D}^{26}=-41.6\left(c 1, \mathrm{CHCl}_{3}\right)$; IR (ATR): $v 1695$, 1552, 1494, $1432 \mathrm{~cm}^{-1} .{ }^{1} \mathrm{H}$ NMR (300 MHz, $\mathrm{CDCl}_{3}$ ): $\delta 3.04$ (s, $\left.3 \mathrm{H}, \mathrm{NCH}_{3}\right), 3.34(\mathrm{~d}, J=8.2 \mathrm{~Hz}, 1 \mathrm{H}, \mathrm{C}=\mathrm{CCHCHCH}), 3.68(\mathrm{dd}, J=$ 10.6, $5.7 \mathrm{~Hz}, 1 \mathrm{H}, \mathrm{C}=\mathrm{CCHCH}), 4.12(\mathrm{dd}, J=10.9,8.6 \mathrm{~Hz}, 1 \mathrm{H}$, $\mathrm{NCHCHPh}), 4.24$ (d, $J=10.9 \mathrm{~Hz}, 1 \mathrm{H}, \mathrm{NCHCHPh}), 4.46(\mathrm{t}, J=8.1$ $\mathrm{Hz}, 1 \mathrm{H}, \mathrm{NCHC}=\mathrm{C}$ ), 4.75 (d, J=4.4 Hz, 1H, NCHPh), 5.20 (dd, J $=8.5,4.5 \mathrm{~Hz}, 1 \mathrm{H}, \mathrm{CHNO}_{2}$ ), 6.16 (dd, $J=15.7,8.0 \mathrm{~Hz}, 1 \mathrm{H}$, $\mathrm{PhCH}=\mathrm{CH}), 6.68(\mathrm{~d}, J=15.7 \mathrm{~Hz}, 1 \mathrm{H}, \mathrm{PhCH}=\mathrm{CH}) 7.08-7.41(\mathrm{~m}$, $15 \mathrm{H}, \mathrm{ArH}) \mathrm{ppm} ;{ }^{13} \mathrm{C}$ NMR $\left(\mathrm{CDCl}_{3}\right): \delta_{\mathrm{C}} 25.7\left(\mathrm{NCH}_{3}\right), 48.0$ ( $\mathrm{C}=\mathrm{CCHCHCH}), 49.1 \quad(\mathrm{C}=\mathrm{CCHCH}), 56.1 \quad(\mathrm{NCHCHPh}), 68.7$ ( $\mathrm{NCHC}=\mathrm{C}), 70.7$ ( $\mathrm{NCHPh}$ ), 73.0 ( $\mathrm{NCHCHPh}), 102.9\left(\mathrm{CH}_{3} \mathrm{NO}_{2}\right)$, $125.6(\mathrm{PhCH}=\mathrm{CH}), 126.3,127.2,127.7,128.3,128.4,128.9$, 129.4, 129.8 (ArC), 134.8 ( $\mathrm{PhCH}=\mathrm{CH}), 135.6,136.5,140.5$ (ArC) 175.4 (NCO), 177.4 (NCO) ppm; MS (El): $m / z 493$ (M+$\left.\mathrm{NO}_{2}, 2 \%\right), 460$ (12), 459 (33), 457 (16), 451 (27), 450 (100), 444 (80), 436 (33), 429 (32), 428 (69), 427 (26), 370 (12), 343 (30), 341 (59), 268 (17), 267 (13), 256 (63), 255 (79), 253 (77), 193 (80), 168 (72), 116 (20), 115 (93), 105 (69), 77 (43); HRMS (DIP) calcd. for $\mathrm{C}_{30} \mathrm{H}_{27} \mathrm{~N}_{3} \mathrm{O}_{4} 493.2002$, found 493.1889.

\subsection{2 (3aS, $4 S, 6 S, 7 R, 8 S, 8 \mathrm{a} R, 8 \mathrm{~b} R)$-2-Methyl-7-nitro-6,8-} diphenyl-4-[(E)-styryl]hexahydropyrrolo[3,4a]pyrrolizine-1,3(2H,8bH)-dione, endo-3a

Brown oil. Yield 36\%. $[\alpha]_{D}^{28}=-23.3\left(c 1.2, \mathrm{CHCl}_{3}\right)$. IR (ATR): $v$ 1697, 1550, 1492, $1434 \mathrm{~cm}^{-1} .{ }^{1} \mathrm{H}$ NMR (300 MHz, $\left.\mathrm{CDCl}_{3}\right): \delta$ $3.18\left(\mathrm{~s}, 3 \mathrm{H}, \mathrm{NCH}_{3}\right), 3.44(\mathrm{dd}, J=8.3,1.9 \mathrm{~Hz}, 1 \mathrm{H}, \mathrm{C}=\mathrm{CCHCHCH})$, $3.63(\mathrm{t}, J=8.5 \mathrm{~Hz}, 1 \mathrm{H}, \mathrm{C}=\mathrm{CCHCH}), 4.30(\mathrm{~m}, 3 \mathrm{H}, \mathrm{NCHCHPh}$, $\mathrm{NCHCHPh}, \mathrm{NCHC}=\mathrm{C}), 4.33-4.36(\mathrm{~m}, 1 \mathrm{H}, \mathrm{NCHPh}), 4.98(\mathrm{t}, J=$ $\left.8.2 \mathrm{~Hz}, 1 \mathrm{H}, \mathrm{CHNO}_{2}\right), 6.1(\mathrm{dd}, J=15.8,5.1 \mathrm{~Hz}, 1 \mathrm{H}, \mathrm{PhCH}=\mathrm{CH}$ ), 6.68 (dd, $J=15.8,1.6 \mathrm{~Hz}, 1 \mathrm{H}, \mathrm{PhCH}=\mathrm{CH}), 7.30-7.41(\mathrm{~m}, 15 \mathrm{H}$, ArH) ppm. ${ }^{13} \mathrm{C} \quad \mathrm{NMR} \quad\left(\mathrm{CDCl}_{3}\right): \delta \quad 15.4 \quad\left(\mathrm{NCH}_{3}\right), \quad 49.5$ ( $\mathrm{C}=\mathrm{CCHCHCH}), 52.2 \quad(\mathrm{C}=\mathrm{CCHCH}), 60.51 \quad(\mathrm{NCHCHPh}), 65.6$ $(\mathrm{NCHC}=\mathrm{C}), 70.6(\mathrm{NCHPh}), 70.81(\mathrm{NCHCHPh}), 91.7\left(\mathrm{CH}_{3} \mathrm{NO}_{2}\right)$, $127.4,127.8,127.9,128.6,129.1,129.2,129.5,130.34$, 132.0, 133.2, 135.0, 163.5, $169.3(\mathrm{PhCH}=\mathrm{CH}, \mathrm{PhCH}=\mathrm{CH}, \mathrm{ArC})$, 169.5 (CO) 179.2 (CO) ppm. MS (EI): $m / z 493\left(\mathrm{M}^{+}-\mathrm{NO}_{2}, 2 \%\right)$, 460 (12), 459 (33), 457 (16), 451 (27), 450 (100), 444 (80), 436 (33), 429 (32), 428 (69), 427 (26), 370 (12), 343 (30), 341 (59), 268 (17), 267 (13), 256 (63), 255 (79), 253 (77), 193 (80), 168 (72), 116 (20), 115 (100), 105 (69), 77 (43). HRMS (DIP) calcd. for $\mathrm{C}_{30} \mathrm{H}_{27} \mathrm{~N}_{3} \mathrm{O}_{4} 493.2002$, found 493.1889 .

\subsection{3 (3aR, $4 R, 6 S, 7 R, 8 S, 8 \mathrm{a} S, 8 \mathrm{bS})-7-$ Nitro-2,6,8-} triphenyl-4-[(E)-styryl]hexahydropyrrolo[3,4a]pyrrolizine-1,3(2H,8bH)-dione endo- $4 \mathrm{~b}$ and $(3 \mathrm{a} S, 4 S, 6 S, 7 R, 8 S, 8 \mathrm{a} R, 8 \mathrm{~b} R)$-7-nitro-2,6,8-triphenyl-4-[(E)styryl]hexahydropyrrolo[3,4-a]pyrrolizine-1,3(2H,8bH)dione, endo-3b

Yellow oil. Yield 81\%. IR (ATR): $v$ 1720, $1550 \mathrm{~cm}^{-1} .{ }^{1} \mathbf{H}$ NMR (300 MHz, $\mathrm{CDCl}_{3}$ ): (1:1) mixture of diastereoisomers: $\delta 3.49$ (dd, $J=8.3,1.3 \mathrm{~Hz}, 1 \mathrm{H}), 3.58(\mathrm{dd}, J=8.6,1.7 \mathrm{~Hz}, 1 \mathrm{H}), 3.74(\mathrm{t}$, $J=8.9 \mathrm{~Hz}, 1 \mathrm{H}), 3.83(\mathrm{t}, J=8.3 \mathrm{~Hz}, 1 \mathrm{H}), 4.16(\mathrm{dd}, J=10.6,8.6$ $\mathrm{Hz}, 1 \mathrm{H}), 4.33-4.57(\mathrm{~m}, 6 \mathrm{H}), 4.79(\mathrm{~d}, J=4.6 \mathrm{hz}, 1 \mathrm{H}), 5.06(\mathrm{dd}, J$ $=10.7,6.7 \mathrm{~Hz}, 1 \mathrm{H}), 5.22(\mathrm{dd}, J=8.5,4.7 \mathrm{~Hz}, 1 \mathrm{H}), 6.11(\mathrm{dd}, J=$ $15.8,4.9 \mathrm{~Hz}, 1 \mathrm{H}), 6.23(J=15.7,7.6 \mathrm{~Hz}, 1 \mathrm{H}), 6.72(\mathrm{dd}, J=15.8$, $1.7 \mathrm{~Hz}, 1 \mathrm{H}), 6.74(\mathrm{~d}, J=15.7 \mathrm{~Hz}, 1 \mathrm{H}), 7.19-7.60(\mathrm{~m}, 4 \mathrm{H}) \mathrm{ppm}$. ${ }^{13} \mathrm{C} \mathrm{NMR}\left(\mathrm{CDCl}_{3}\right): \delta 29.7,48.3,48.8,50.2,50.4,53.8,55.9$, $65.1,68.4,70.5,72.372 .4,73.0,98.7,102.5$ ppm. MS (EI): $\mathrm{m} / \mathrm{z} 510\left(\mathrm{M}^{+}, 4 \%\right), 509$ (38), 450 (13), 436 (21), 378 (36), 334 (60), 329 (22), 317 (15), 316 (24), 282 (30), 258 (70), 232 (44), 190 (100), 115 (25); HRMS (DIP) calcd. for 555.22, found 555.22 .

\subsection{4 (3aR,4R,6S,7R,8S,8aS,8bS)-2-(4-Bromophenyl)-} 7-nitro-6,8-diphenyl-4-[(E)-styryl]hexahydropyrrolo[3,4a]pirrolizine-1,3(2H,8bH)-dione, endo-3c

Pink oil. Yield $80 \%$. $[\alpha]_{D}^{28}=-92.3$ (c 1, $\mathrm{CHCl}_{3}$ ). IR (ATR): $v$ 2921, 2851, 1710, 1546, $1491 \mathrm{~cm}^{-1} .{ }^{1} \mathrm{H}$ NMR $(300 \mathrm{MHz}$, $\left.\mathrm{CDCl}_{3}\right): \delta 3.49(\mathrm{dd}, J=8.3,1.3 \mathrm{~Hz}, 1 \mathrm{H}, \mathrm{C}=\mathrm{CCHCHCH}), 3.85(\mathrm{t}, J$ $=8.3 \mathrm{~Hz}, 1 \mathrm{H}, \mathrm{C}=\mathrm{CCHCH}), 4.15(\mathrm{dd}, J=10.5,8.6 \mathrm{~Hz}, 1 \mathrm{H}$, $\mathrm{NCHCHPh}), 4.35$ (d, $J=10.6 \mathrm{~Hz}, 1 \mathrm{H}, \mathrm{NCHCHPh}), 4.56$ (t, $J=7.7$ $\mathrm{Hz}, 1 \mathrm{H}, \mathrm{NCHC}=\mathrm{C}), 4.78(\mathrm{~d}, J=4.7 \mathrm{~Hz}, 1 \mathrm{H}, \mathrm{NCHPh}), 5.22$ (dd, $J$ $\left.=8.5,4.7 \mathrm{~Hz}, 1 \mathrm{H}, \mathrm{CHNO}_{2}\right), 6.21(\mathrm{dd}, J=15.7,7.5 \mathrm{~Hz}, 1 \mathrm{H}$, $\mathrm{PhCH}=\mathrm{CH}), 6.74(\mathrm{~d}, J=15.7 \mathrm{~Hz}, 1 \mathrm{H}, \mathrm{PhCH}=\mathrm{CH}) 7.14-7.57(\mathrm{~m}$, $15 \mathrm{H}, \mathrm{ArH}) \mathrm{ppm} .{ }^{13} \mathrm{C} \mathrm{NMR}\left(\mathrm{CDCl}_{3}\right)$ : $\delta 48.6$ (CHPhCHCHCO), 49.0 ( $\mathrm{C}=\mathrm{CHCHCHCO}) \quad 56.1$ (NCHCHPh), $68.6 \quad(\mathrm{C}=\mathrm{CHCH}), 70.9$ ( $\mathrm{NCHPh}), 73.2(\mathrm{NCHCHPh}), 102.5\left(\mathrm{CHNO}_{2}\right), 122.9(\mathrm{PhCH}=\mathrm{CH})$, $134.6(\mathrm{PhCH}=\mathrm{CH}), 125.2,126.2,127.1,127.6,128.1,128.4$, 128.8, 129.4, 132.6, 135.6, 136.2, 140.2 (ArC), 174.1 (NCO), 176.0 (NCO) ppm. MS (EI): $m / z 586\left(\mathrm{M}^{+}-\mathrm{NO}_{2}, 40 \%\right), 584$ (37), 571 (32), 570 (98), 569 (48), 568 (93), 567 (16), 482 (23), 480 (16), 396 (15), 394 (21), 343 (24), 256 (30), 255 (32), 254 (22), 239 (17), 219 (19), 193 (64), 178 (18), 168 (67), 167 (30), 165 (16), 154 (18), 141 (17), 128 (17), 117 (30), 116 (27), 115 (100), 91 (50), 90 (24), 89 (26), 77 (43), 63 (17). HRMS (DIP) calcd. for $\mathrm{C}_{36} \mathrm{H}_{29} \mathrm{~N}_{3} \mathrm{O}_{4}\left(-\mathrm{NO}_{2}\right) 586.1141$, found 586.1108 .

3.3.5 (1R,2R,3S,5S,6R,7S,7aR)-Dimethyl 6-nitro-5,7diphenyl-3-[(E)-styryl]hexahydro-1H-pyrrolizine-1,2dicarboxylate, endo-3d

White solid (hexane/ethyl acetate). Yield $76 \%$. Melting Point: 148-154. $[\alpha]_{D}^{26}=-28.3$ (c 1, $\mathrm{CHCl}_{3}$ ). IR (ATR): $v$ 1734, 1550, 1495, $1437 \mathrm{~cm}^{-1} .{ }^{1}{ }^{H}$ NMR (300 MHz, CDCl $_{3}$ ): $\delta 3.49$ (dd, $J=12.6,10.5 \mathrm{~Hz}, 1 \mathrm{H}, \mathrm{C}=\mathrm{CCHCH}), 3.51\left(\mathrm{~s}, 3 \mathrm{H}, \mathrm{CO}_{2} \mathrm{CH}_{3}\right), 3.66$ (dd, $J=9.8,7.5 \mathrm{~Hz}, 1 \mathrm{H}, \mathrm{C}=\mathrm{CCHCHCH}), 3.73\left(\mathrm{~s}, 3 \mathrm{H}, \mathrm{CO}_{2} \mathrm{CH}_{3}\right)$, 4.0-4.19 (m, 2H, NCHCHPh, NCHCHPh), $4.30(\mathrm{t}, J=7.1 \mathrm{~Hz}, 1 \mathrm{H}$, $\mathrm{NCHC}=\mathrm{C}), 4.72(\mathrm{~d}, J=8 \mathrm{~Hz}, 1 \mathrm{H}, \mathrm{NCHPh}), 5.16(\mathrm{t}, J=8.6 \mathrm{~Hz}, 1 \mathrm{H}$, $\mathrm{CHNO}_{2}$ ), $6.03(\mathrm{dd}, J=15.7,7.4 \mathrm{~Hz}, 1 \mathrm{H}, \mathrm{PhCH}=\mathrm{CH}), 6.41$ (d, $J=$ 
$15.8 \mathrm{~Hz}, 1 \mathrm{H}, \mathrm{PhCH}=\mathrm{CH})$ 7.18-7.47 (m, 15H, $\mathrm{ArH}) \mathrm{ppm} ;{ }^{13} \mathrm{C} \mathrm{NMR}$ $\left(\mathrm{CDCl}_{3}\right) \delta_{\mathrm{C}}: 51.2\left(\mathrm{OCH}_{3}\right), 52.3\left(\mathrm{OCH}_{3}\right), 52.6(\mathrm{NCHCHPh}), 55.0$ $(\mathrm{C}=\mathrm{CCHCH} \quad \mathrm{C}=\mathrm{CCHCHCOCH}), \quad 56.0 \quad(\mathrm{C}=\mathrm{CCHCH} \quad 0$ $\mathrm{C}=\mathrm{CCHCHCOCH}), \quad 71.2 \quad(\mathrm{NCHC}=\mathrm{C}), 71.5 \quad$ (NCHPh), 72.6 (NCHCHPh), $99.9\left(\mathrm{CHNO}_{2}\right), 126.6,127.3,127.5,127.9,128.3$, 128.5, 128.9, 128.9, 129.2, 133.0, $136.1 \quad(\mathrm{PhCH}=\mathrm{CH}$, $\mathrm{PhCH}=\mathrm{CH}, \mathrm{ArC}), 171.2,172.0$ (CO) ppm. MS (EI): $\mathrm{m} / \mathrm{z} 480\left(\mathrm{M}^{+}\right.$ -NO $2,<2 \%), 376$ (12), 344 (16), 194 (15), 193 (100), 178 (12), 115 (53), 105 (25). HRMS (DIP) calcd. for $\mathrm{C}_{26} \mathrm{H}_{25} \mathrm{~N}_{3} \mathrm{O}_{6}\left(-\mathrm{NO}_{2}\right)$ 480.2175 , found 480.2179 .

\subsection{6 (1S,2R,3S,5S,6R,7R,7aR)-2-nitro-1,3-diphenyl-} 6,7-bis(phenylsulfonyl)-5-[(E)-styryl]hexahydro-1Hpyrrolizine, endo-3e

Brown oil. Yield 50\%. $[\alpha]_{D}^{28}=22.3$ (c 1.2, $\mathrm{CHCl}_{3}$ ). IR (ATR): $v$ 1730, 1548, 1494, $1448 \mathrm{~cm}^{-1}$. ${ }^{1} \mathbf{H}$ NMR (300 MHz, CDCl 3 ): $\delta$ 3.75 (m, 1H, NCHCHPh), 4.11 (m, 1H, CHS), 4.47 (t, $J=12.1$ $\mathrm{Hz}, 1 \mathrm{H}, \mathrm{NCHCHPh}), 4.79$ (dd, $J=14.4,9.0 \mathrm{~Hz}, 1 \mathrm{H}, \mathrm{CHS}$ ), 5.24 (m, 1H, NCHPh), 5.47 (dd, $J=12.2,8.0 \mathrm{~Hz}, 1 \mathrm{H}, \mathrm{CHNO}_{2}$ ), 5.81 $(\mathrm{d}, J=7.4 \mathrm{~Hz}, 1 \mathrm{H}, \mathrm{PhCH}=\mathrm{CH}), 6.11(\mathrm{~d}, J=8.2 \mathrm{~Hz}, 1 \mathrm{H}$, $\mathrm{PhCH}=\mathrm{CH}), 7.12-7.45(\mathrm{~m}, 25 \mathrm{H}, \mathrm{ArH}) \mathrm{ppm} .{ }^{13} \mathrm{C} \mathrm{NMR}\left(\mathrm{CDCl}_{3}\right): \delta$ 46.3 (NCHCHPh), 48.3 ( $\left.\mathrm{CSO}_{2} \mathrm{Ph}\right), 50.6 \quad\left(\mathrm{CSO}_{2} \mathrm{Ph}\right), 55.5$ ( $\left.\mathrm{CSO}_{2} \mathrm{Ph}\right), 64.4$ (NCHCHPh), 64.4 (C=CCH), 68.7 (NCHPh), 95.2 $\left(\mathrm{CHNO}_{2}\right), 96.16,125.4,126.8,127.0,127.1,127.3,127.8$, 128.0, 128.6, 128.7, 128.8, 129.0, 129.0, 129.1, 129.3, 129.5, 129.6, 129.7, 129.7, 130.0 ( $\mathrm{ArC}, \mathrm{PhCH}=\mathrm{CH}, \mathrm{PhCH}=\mathrm{CH})$ ppm. MS (EI): $m / z 644$ (M+-NO, $3 \%), 194$ (35), 193 (100), 178 (14), 168 (17), 115 (52), 91 (15). HRMS (DIP) calcd. for $\mathrm{C}_{26} \mathrm{H}_{25} \mathrm{~N}_{3} \mathrm{O}_{6}\left(-\mathrm{C}_{6} \mathrm{H}_{5} \mathrm{SNO}_{4}\right)$ 503.1919, found 503.1901.

\subsection{7 (1S,2S,3R,5S,6R,7S,7aR)-dimethyl 6-nitro-3,5,7-} triphenylhexahydro-1H-pyrrolizine-1,2-dicarboxylate (major), endo-3f

Blue oil. Yield 84\%. IR (ATR): $v$ 1733, 1552, 1492, $1436 \mathrm{~cm}^{-1}$. ${ }^{1} \mathrm{H} \quad \mathrm{NMR} \quad\left(300 \mathrm{MHz}, \mathrm{CDCl}_{3}\right): 64: 44$ mixture of diastereoisormers: $\delta 3.08\left(\mathrm{~s}, 1.5 \mathrm{H}, \mathrm{CH}_{3}\right), 3.42\left(\mathrm{~s}, 1.5 \mathrm{H}, \mathrm{CH}_{3}\right)$, $3.53\left(\mathrm{~s}, 3 \mathrm{H}, \mathrm{CH}_{3}\right), 3.60$ (dd, J = 9.5, $8.4 \mathrm{~Hz}, 1 \mathrm{H}$, $\mathrm{PhCHCHCOCHCO}), 3.69\left(\mathrm{~s}, 3 \mathrm{H}, \mathrm{CH}_{3}\right), 3.72$ (dd, $J=9.6,7.2 \mathrm{~Hz}$, $1 \mathrm{H}, \mathrm{PhCHCHCO}$ ), 3.80 (dd, $J=11.3,8.5 \mathrm{~Hz}, 0,5 \mathrm{H}, \mathrm{PHCHCHCO}$ ), $3.96(\mathrm{t}, J=10.4 \mathrm{~Hz}, 0,5 \mathrm{H}, \mathrm{PhCHCHCOCHCO}), 4.21(\mathrm{t}, J=7.7 \mathrm{~Hz}$, $1 \mathrm{H}, \mathrm{NCHCHPh}), 4.31(\mathrm{t}, J=7.4 \mathrm{~Hz}, 1 \mathrm{H}, \mathrm{NCHCHPh}), 4.48(\mathrm{~d}, J=$ $8.4 \mathrm{~Hz}, 1 \mathrm{H}, \mathrm{PhCHCHCO}), 4.57-4.75(\mathrm{~m}, 1.5 \mathrm{H}, \mathrm{NCHCHPh}$, $\mathrm{PhCHCHCO}, \mathrm{NCHPh}), 4.71$ (d, J = 7.6 Hz, 1H, NCHPh), 4.93 (d, $\left.J=10.3,7.9 \mathrm{~Hz}, 0.5 \mathrm{H}, \mathrm{CHNO}_{2}\right) 5.12(\mathrm{dd}, J=8.9,7.7 \mathrm{~Hz}, 1 \mathrm{H}$, $\left.\mathrm{CHNO}_{2}\right), 7.18-7.38(\mathrm{~m}, 22.5 \mathrm{H}, \mathrm{ArH}) \mathrm{ppm} .{ }^{13} \mathrm{C} \mathrm{NMR}\left(\mathrm{CDCl}_{3}\right): \delta$ 46.9, 49.8, 51.5, 51.9, 52.4, 52.6, 52.7, 53.4, 56.1, 57.7, 69.1, 70.0, 72.8, 73.6, 73.7, $99.7\left(\mathrm{CHNO}_{2}\right), 100.8\left(\mathrm{CHNO}_{2}\right), 125.5$, $126.6,127.1,127.2,127.6,127.8,127.9,128.0,128.3,128.5$, $128.6,128.8,129.0,129.1,129.3,129.6,135.4,137.3,138.9$, 139.4, 140.3, 170.3 ( $\mathrm{C}=0), 170.9(\mathrm{C}=0), 171.8(\mathrm{C}=0), 172.8$ (C=O) ppm. MS (EI): $\mathrm{m} / \mathrm{z} 454\left(\mathrm{M}^{+}-\mathrm{NO}_{2}, 26 \%\right), 308$ (19), 232 (20), 195 (24), 194 (15), 194 (100), 193 (16), 191 (38), 179 (20), 178 (85), 165 (23), 129 (15), 128 (17), 116 (71), 115 (94), 91 (76), 77 (21). HRMS (DIP): calcd. for $\mathrm{C}_{26} \mathrm{H}_{25} \mathrm{~N}_{3} \mathrm{O}_{6}\left(-\mathrm{NO}_{2}\right)$ 480.2018 , found 454.2027.
3.3.8 (4S,6S,7R,8S,8aR)-2-Methyl-7-nitro-4phenethyl-6,8-diphenylhexahydropyrrolo[3,4a]pyrrolizine-1,3(2H, 8bH)-dione (major) endo-4g and (3aR,4R,6S,7R,8S,8aS,8bS)-2-methyl-7-nitro-4phenethyl-6,8-diphenylhexahydro-pyrrolo[3,4a]pyrrolizine-1,3(2H,8bH)-dione (minor), endo-3g Yellow oil. Yield 23\%. IR (ATR): $v$ 1728, 1536, $1489 \mathrm{~cm}^{-1} .{ }^{1} \mathbf{H}$ NMR (300 MHz, $\mathbf{C D C l}_{3}$ ): $\delta$ (diastereoisomers mixture $(1.0: 0.6)): 1.73(\mathrm{~m}, 3.2 \mathrm{H}), 2.37(\mathrm{~m}, 1.2 \mathrm{H}), 2.70(\mathrm{~m}, 1.6 \mathrm{H}), 2.92$ $(\mathrm{m}, 0.6 \mathrm{H}), 3.02(\mathrm{~s}, 1.3 \mathrm{H}), 3.21(\mathrm{~d}, J=8.3 \mathrm{~Hz}, 1 \mathrm{H}), 3.39(\mathrm{~m}$, $0.6 \mathrm{H}), 3.56-3.74(\mathrm{~m}, 3 \mathrm{H}), 4.00(\mathrm{dd}, J=, 0.6 \mathrm{H}), 4.09(\mathrm{~s}, 0.6 \mathrm{H})$, 4.24-4.33 (m, $2.2 \mathrm{H}), 4.6(\mathrm{~d}, J=5.8 \mathrm{~Hz}, 0.6 \mathrm{H}), 5.02(\mathrm{dd}, J=8.8$, $7.9 \mathrm{~Hz}, 1 \mathrm{H}), 5.10(\mathrm{dd}, \mathrm{J}=8.5,5.8 \mathrm{~Hz}, 1 \mathrm{H}) \mathrm{ppm} .{ }^{13} \mathrm{C}$ NMR ( $\left.\mathrm{CDCl}_{3}\right)$ : $\delta$ 25.2, 25.6, 32.7, 32.8, 33.0, 37.6, 47.2, 49.7, 50.1, $53.1,55.3,64.3,71.5,72.0,72.8,96.7,126.0,126.4,127.5$, $128.0,128.2,128.4,128.5,129.1,129.4,129.4,129.5,141.1$, 141.4, 177.3, 178.7 ppm. MS (EI): $\mathrm{m} / \mathrm{z} 495\left(\mathrm{M}^{+}, 5 \%\right), 449$ (33), 421 (10), 405 (20), 391 (60), 390 (80), 371 (48), 357 (41), 344 (22), 343 (43), 336 (14), 270 (15), 190 (100), 152 (45), 115 (20), 70 (12). HRMS (DIP) calcd. 495.22, found 495.22.

\subsubsection{Dimethyl 2,2'-[(1S,2S,3R,5S,6R,7S,7aS)-6-nitro-} 3-phenethyl-5,7-diphenylhexahydro-1H-pyrrolizine-1,2diyl]bis(2-oxoacetate) endo-3h (major) and dimethyl 2,2'-[(1R,2R,3S,5S,6R,7S,7aR)-6-nitro-3-phenethyl-5,7diphenylhexahydro-1H-pyrrolizine-1,2-diyl]bis(2oxoacetate) endo-4h

Pink oil. Yield. 26\%. IR (ATR): $v$ 2832, 1731, 1533, $1494 \mathrm{~cm}^{-1}$. ${ }^{1} \mathrm{H}$ NMR (300 MHz, $\mathrm{CDCl}_{3}$ ): 65:35 mixture of diastereoisomer: ס 1.62-1.82 (m, 2.6H, $\left.\mathrm{CH}_{2}\right), 2.37-2.63\left(\mathrm{~m}, 2.6 \mathrm{H}, \mathrm{CH}_{2}\right), 3.23(\mathrm{~s}$, 1.3H) 3.34-3.37 (m, 2.2 $\left., \mathrm{CH}_{2} \mathrm{CH}, \mathrm{CHCO}_{2} \mathrm{Me}\right), 3.60(\mathrm{~s}, 3 \mathrm{H}$, $\left.\mathrm{CO}_{2} \mathrm{Me}\right), 3.78\left(\mathrm{~s}, 3 \mathrm{H}, \mathrm{CO}_{2} \mathrm{Me}\right), 3.76-3.80\left(\mathrm{~m}, 2 \mathrm{H}, \mathrm{CHCO}_{2} \mathrm{Me}\right.$, NCHCHPh), 4.00 (dd, J = 9.0, $5.2 \mathrm{~Hz}, 1 \mathrm{H}, \mathrm{NCHCHPh}$ ), 4.57 (d, J $=8.6 \mathrm{~Hz}, 1 \mathrm{H}, \mathrm{NCHCHPh}), 5.04\left(\mathrm{t}, J=8.6 \mathrm{~Hz}, 1 \mathrm{H}, \mathrm{CHNO}_{2}\right) .{ }^{13} \mathrm{C}$ NMR ( $\left.\mathrm{CDCl}_{3}\right)$ : 31.6, 23.3, 33.4, 37.2, 51.6, 52.3, 52.7, 53.4, $53.7,54.8,65.3,67.7,73.2,74.0,74.3,89.3,100.3,125.9$, $127.2,127.6,2,127.5,127.9,128.0,128.0,128.1,128.3$, $128.4,128.4,129.0,129.1,129.2,129.3,129.6,138.2,139.1$, 141.6, 171.3, 171.4, 172.3, 173.7 ppm. MS(EI): $m / z 528\left(\mathrm{M}^{+}\right.$, 2\%), 482 (64), 469 (12), 423 (100), 410 (32), 402 (12), 384 (10), 314 (18), 195 (21), 118 (19), 114 (64). HRMS (DIP): calcd. for 528.3311, found 528.3311.

\subsubsection{0 (6S,7R,8S,8aR)-2,4-dimethyl-7-nitro-4- phenethyl-6,8-diphenylhexahydropyrrolo[3,4- a]pyrrolizine-1,3(2H,8bH)-dione, endo-3i}

Brown oil. Yield 47\%. $[\alpha]_{D}^{25}=102.3$ (c 1, $\mathrm{CHCl}_{3}$ ). IR (ATR): $v$ 1733, 1551, $1494 \mathrm{~cm}^{-1} .{ }^{1} \mathrm{H}$ NMR (300 MHz, $\left.\mathrm{CDCl}_{3}\right): \delta 1.48(\mathrm{~s}$, $\left.1 \mathrm{H}, \mathrm{CH}_{3}\right), 3.03\left(\mathrm{~s}, 3 \mathrm{H}, \mathrm{NCH}_{3}\right), 3.37(\mathrm{~d}, J=8.2 \mathrm{~Hz}, 1 \mathrm{H}, \mathrm{CCHCO})$, $3.58(\mathrm{t}, J=8.7 \mathrm{~Hz}, 1 \mathrm{H}, \mathrm{NCHCHCO}), 4.35(\mathrm{t}, J=8.5 \mathrm{~Hz}, 1 \mathrm{H}$, $\mathrm{NCHCHPh}$ ), 4.55 (dd, $J=9.0,7.9 \mathrm{~Hz}, 1 \mathrm{H}, \mathrm{NCHCHPh}), 4.73$ (d, J $=7.6 \mathrm{~Hz}, 1 \mathrm{H}, \mathrm{NCHPh}), 4.95\left(\mathrm{dd}, J=8.9,7.7 \mathrm{~Hz}, 1 \mathrm{H}, \mathrm{CHNO}_{2}\right.$ ) $6.19(\mathrm{~d}, J=16.1 \mathrm{~Hz}, 1 \mathrm{H}, \mathrm{PhCH}=\mathrm{CH}), 6.42(\mathrm{~d}, J=16.1 \mathrm{~Hz}, 1 \mathrm{H}$, $\mathrm{PhCH}=\mathrm{CH}), 7.07-7.41(15 \mathrm{H}, \mathrm{ArCH}) \mathrm{ppm} .{ }^{13} \mathrm{C} \mathrm{NMR}\left(\mathrm{CDCl}_{3}\right): \delta$ $25.0\left(\mathrm{CH}_{3}\right), 26.5\left(\mathrm{CH}_{3}\right), 48.3(\mathrm{CH}), 51.8(\mathrm{CH}), 59.1(\mathrm{CH}), 67.4$ $(\mathrm{CH}), 68.0(\mathrm{CH}), 71.6(\mathrm{CH}), 101.9(\mathrm{CH}), 122.8,126.3,126.5$, 
127.6, 128.0, 128.0, 128.3, 129.1, 132.7, 136.1, 138.3, 140.7 ( $\mathrm{ArC}, \mathrm{PhCH}=\mathrm{CH}, \mathrm{PhCH}=\mathrm{CH}$ ), 175.3 (CO), 176.5 (CO) ppm. MS (EI): $m / z 507$ (M 5\%), 492 (38), 461 (68), 430 (23), 404 (55), 396 (14), 359 (100), 274 (21), 193 (30), 80 (12). HRMS (DIP): calcd. for 507.2203, found 507.2203.

3.3.11 dimethyl 2,2'-((1S,2S,3R,5S,6R,7S,7aS)-3methyl-6-nitro-5,7-diphenyl-3-((E)-styryl)hexahydro-1Hpyrrolizine-1,2-diyl)bis(2-oxoacetate), endo-3j

Blue oil. Yield 30\%. $[\alpha]_{D}^{28}=70.2\left(1 \mathrm{c}, \mathrm{CHCl}_{3}\right.$ ). IR (ATR): $v 2831$, 1730, 1542, $1467 \mathrm{~cm}^{-1} .{ }^{1} \mathbf{H}$ NMR (300 MHz, CDCl 3 ): $\delta 1.36(\mathrm{~s}$, $\left.3 \mathrm{H}, \mathrm{CCH}_{3}\right), 3.28\left(\mathrm{~s}, 3 \mathrm{H}, \mathrm{CO}_{2} \mathrm{CH}_{3}\right), 3.59\left(\mathrm{~s}, 3 \mathrm{H}, \mathrm{CO}_{2} \mathrm{CH}_{3}\right), 3.65-$ $3.74\left(\mathrm{~m}, 2 \mathrm{H}, \mathrm{CHCO}_{2} \mathrm{Me}, \mathrm{CHCO}_{2} \mathrm{Me}\right), 3.96(\mathrm{t}, J=10.6 \mathrm{~Hz}$, $\mathrm{NCHCHPh}$ ), 4.23 (dd, J = 9.9, $8.3 \mathrm{~Hz}, 1 \mathrm{H}, \mathrm{NCHCHPh}), 4.86$ (d, J $=8.2 \mathrm{~Hz}, 1 \mathrm{H}, \mathrm{NCHPh}), 5.07\left(\mathrm{dd}, J=10.6,8.2 \mathrm{~Hz}, 1 \mathrm{H}, \mathrm{CHNO}_{2}\right.$ ), $6.34(\mathrm{~d}, J=16,1 \mathrm{~Hz}, 1 \mathrm{H}, \mathrm{CH}=\mathrm{CH}), 6.41(\mathrm{~d}, J=16,1 \mathrm{~Hz}, 1 \mathrm{H}$, $\mathrm{CH}=\mathrm{CH}), 7.23-7.44(\mathrm{~m}, 15 \mathrm{H}, \mathrm{ArH}) \mathrm{ppm} .{ }^{13} \mathrm{C} \mathrm{NMR}\left(\mathrm{CDCl}_{3}\right): \delta$ $25.5\left(\mathrm{CCH}_{3}\right), 49.9$ (C), $52.0\left(\mathrm{OCH}_{3}\right), 52.4\left(\mathrm{OCH}_{3}\right), 58.9$ $\mathrm{NCHCHPh}), \quad 60.3\left(\mathrm{CHCO}_{2} \mathrm{CH}_{3}\right), 60.9\left(\mathrm{CHCO}_{2} \mathrm{CH}_{3}\right), \quad 67.0$ (NCHCHPh), 72.2 (NCHPh), $101.2\left(\mathrm{CHNO}_{2}\right), 126.9,126.9$, 127.6, 128.3, 128.4, 128.5, 128.9, 128.9, 129.0, 129.3, 129.6, 133.8, 135.4, 136.4, 141.0 ( $\mathrm{ArC}, \mathrm{PhCH}=\mathrm{CH}, \mathrm{PhCH}=\mathrm{CH}), 171.3$ $\left(\mathrm{CO}_{2} \mathrm{CH}_{3}\right), 172.2\left(\mathrm{CO}_{2} \mathrm{CH}_{3}\right)$. MS (EI): $\mathrm{m} / z 596\left(\mathrm{M}^{+}, 5 \%\right), 525$ (34), 495 (12), 493 (82), 350 (27), 243 (100), 220 (48), 194 (21), 193 (15), 77 (17). HRMS (DIP): calcd. for 593.6303, found 593.6303 .

\section{CONCLUSION}

Enantiopure exo-4-nitro-3,5-diphenylproline reacted satisfactorily with aldehydes or 4-phenyl-3-buten-2-one and electrophilic alkenes in a multicomponent 1,3-dipolar cycloaddition. The decarboxylation occurred at room temperature but the cycloaddition took place at different temperatures depending on the nature of the aldehyde involved. The negative charge of the dipole is located at the

\section{REFERENCES}

[1] Robertson, J.; Stevens, K. Nat. Prod. Rep. 2017, 34, 62-89.

[2] Jank, B.; Rath, J. Trends Plant Sci. 2017, 22, 191-193.

[3] Kotsiou, A.; Christine, T. J. Med. Plant Studies 2017, 5, 80-88.

[4] Habs, M.; Binder, K.; Krauss, S.; Muller, K.; Koller, M.; Ernst, B.; Valentini, L. Nutrients 2017, 9, 717-738.

[5] Glycosidase inhibition is a common general biological property of these pyrrolizidine alkaloids: Watson, A. A.; Fleet, G. W. J.; Asano, N.; Molyneux, R. J.; Nash, R. J. Phytochem. 2001, 53, 265-295.

[6] Davies, S. G.; Fletcher, A. M.; Roberts, P. M.; Thomson, J. E. Synthesis 2017, DOI: 10.1055/s-0036-1590975.

[7] (a) Sengupta, T.; Khamarui, S.; Samanta, S.; Maiti, D. K. Chem. Commun. 2013, 49, 9962-9964; (b) Mancebo-Aracil, J.; Nájera, C.; Sansano, J. M. Chem. Commun. 2013, 49, 1121811220; (c) Mancebo-Aracil, J.; Nájera, C.; Castelló, L. M.; Sansano, J. M.; Larrañaga, O.; de Cózar, A.; Cossío, F. P. Tetrahedron 2015, 71, 9645-9661; (d) Khlebnikov, A. F.; Novikov, M. S.; Kostikov, R. R. Russ. Chem. Rev. 2005, 74, allylic position such as it was depicted in Figure 4. This dipole reacted by its two faces also depending of the structure of the electrophilic alkene, but always following an endo-approach towards the dipole. The preference of the attack is controlled by a esteroelectronic repulsion of the alkene with the nitro group and also by a possible $\pi$-interaction with the phenyl group bonded to $\mathrm{C}(3)$ atom. Thus, NMM attack through an endo down fashion except in the reaction with the unsaturated ketone, but $\mathrm{N}$-aryl maleimides approached via endo up route. Dimethyl fumarate and BPSE both preferred the attack through the endo ${ }^{\text {up }}$ manner.

\section{CONFLICT OF INTEREST}

The authors declare no conflict of interest.

\section{ACKNOWLEDGEMENTS}

We gratefully acknowledge financial support from the Spanish Ministerio de Economía y Competitividad (MINECO) (projects CTQ2013-43446-P and CTQ2014-51912-REDC), the Spanish Ministerio de Economía, Industria y Competitividad, Agencia Estatal de Investigación (AEI) and Fondo Europeo de Desarrollo Regional (FEDER, EU) (projects CTQ2016-76782-P and CTQ2016-81797-REDC), the Generalitat Valenciana (PROMETEO2009/039 and PROMETEOII/2014/ 017) and the University of Alicante.

\section{SUPPLEMENTARY MATERIAL}

Copies of $1 \mathrm{H}$ and $13 \mathrm{C}$ NMR spectra and, their corresponding NOESY-nOe are supplied as Supportive/Supplementary Material. 
171-192; (e) Kang, T.-R.; Cheng, Y.; He, L.; Ye, J.; Liu, Q.-Z. Tetrahedron Lett. 2012, 53, 2552-2555.

[8] In some examples prolinate itself has been generated from a previous 1,3-DC. For selected examples of racemic and nonracemic processes, see: (a) Egorov, V. A.; Khasanova, L. S.; Gimalova, F. A.; Lobov, A. N.; Miftakhov, M. S. Mendeleev Commun. 2017, 27, 163-165; (b) Cui, P.; Xu, L.; Shi, Z.; Gan, L. J. Org. Chem. 2011, 76, 4210-4212; (c) Codelli, J. A.; Puchlopek, A. L. A.; Reisman, S. E. J. Am. Chem. Soc. 2012, 134, 1930-1933; (d) Lu, Q.; Song, G.; Jasinski, J. P.; Keeley, A. C.; Zhang, W. Green Chem. 2012, 14, 3010-3012; (e) Lim, A. D.; Codelli, J. A.; Reisman, S. E. Chem. Sci. 2013, 4, 650-654.

[9] (a) Rajkumar, V.; Babu, S. A.; Padmavathi, R. Tetrahedron 2016, 72, 5578-5594; (b) Pavlovskaya, T. L.; Yaremenko, F. G.; Lipson, V. V.; Shishkina, S. V.; Shishkin, O. V.; Musatov, V. I.; Karpenko, A. S. Beilstein J. Org. Chem. 2014, 10, 117-126.

[10] Felluga, F.; Forzato, C.; Nitti, P.; Pitacco, G.; Valentin, E.; Zangrando, E. J. Heterocyclic Chem. 2010, 47, 664-670.

[11] Concerning the presence of a nitro group in cyclic structures not only allows a series of synthetic transformations but also enhances/modifies the biological properties of such molecules. (a) Parry, R.; Nishino, S.; Spain, J. Nat. Prod. Rep. 2011, 28, 152-167; (b) Nájera, C.; Sansano, J. M. Curr. Top. Med. Chem. 2014, 14, 1271-1282.

[12] Ruíz-Olalla, A.; Retamosa, M. d. G.; Cossío, F. P. J. Org. Chem. 2015, 80, 5588-5599.

[13] Conde, E.; Bello, D.; de Cózar, A.; Sánchez, M.; Vázquez, M. A.; Cossío, F. P. Chem. Sci. 2012, 3, 1486-1491.

[14] Retamosa, M. G.; de Cózar, A.; Sánchez, M.; Miranda, J. I.; Sansano, J. M.; Castelló, L. M.; Nájera, C.; Jiménez, A. I.; Sayago, F. J.; Cativiela, C.; Cossío, F. P. Eur. J. Org. Chem. 2015, 2503-2516.

[15] Conde, E.; Rivilla, I.; Larumbe, A.; Cossío, F. P. J. Org. Chem. 2015, 80, 11755-11767.

[16] For recent and representative examples of sterically congested systems generated by 1,3-DC, see: (a) Yang, W.-L.; Liu, Y.-Z.; Luo, S.; Yu, X.; Fossey, J. S.; Deng, W.-P. Chem. Commun. 2015, 51, 9212-9215; (b) Bharitkar, Y. P.; Das, M.; Kumari, N.; Kumari, M. P.; Hazra, A.; Bhayye, Sagar S.;
Natarajan, R.; Shah, S.; Chatterjee, S.; Mondal, N. B. Org. Lett. 2015, 17, 4440-4443.

[17] Cayuelas, A.; Ortiz, R.; Nájera, C.; Sansano, J. M.; Larrañaga, O.; de Cózar, A.; Cossío, F. P. Org. Lett. 2016, 18, 2926-2929.

[18] Selva, V.; Larrañaga, O.; Castelló, L. M.; Nájera, C.; Sansano, J. M.; de Cózar, A. J. Org. Chem. 2017, 82, 6298-6312

[19] San Sebastián, E.; Zimmerman, T.; Zubia, A.; Vara, Y.; Martin, E.; Sirockin, F.; Dejaegere, A.; Stote, R. H.; López, X.; PantojaUceda, D.; Valcárcel, M.; Mendoza, L.; Vidal-Vanaclocha, F.; Cossío, F. P.; Blanco, F. J. J. Med. Chem. 2013, 56, 735-747.

[20] Zubia, A.; Mendoza, L.; Vivanco, S.; Aldaba, E.; Carrascal, T.; Lecea, B.; Arrieta, A.; Zimmerman, T.; Vidal-Vanaclocha, F.; Cossío, F. P. Angew. Chem. Int. Ed. 2005, 44, 2903-2907.

[21] Narayan, R.; Bauer, J. O.; Strohmann, C.; Antonchick, A. P.; Waldmann, H. Angew. Chem. Int. Ed. 2013, 52, 12892-12896.

[22] Puerto-Galvis, C. E.; Kouznetsov, V. V. Org. Biomol. Chem. 2013, 11, 7372-7386.

[23] Tripathi, R. P.; Bisht, S. S.; Pandey, V. P.; Pandey, S. K.; Singh, S.; Sinha, S. K.; Chaturvedi, V. Med. Chem. Res. 2011, 20, 15151522.

[24] Belveren, S.; Dondas, H. A.; Ülger, M.; Poyraz, S.; GarcíaMingüens, E.; Ferrándiz-Saperas, M.; Sansano, J. M. Tetrahedron 2017, DOI.org/10.1016/j.tet.2017.10.007

[25] Enantiopure tetrasubstituted nitroprolinate surrogates have also been designed as scaffolds for proteasome inhibitors with high medicinal prospects. Cossío, F. P.; Retamosa, M. G.; Larumbe, A.; Zubia, A.; Bello, T.; Vara, Y. I.; Masdeu, C.; Aldaba, E. Patent WO2015/124663, 2015.

[26] (a) Castelló, L. M.; Nájera, C.; Sansano, J. M.; Larrañaga, O.; de Cózar, A.; Cossío, F. P. Org. Lett. 2013, 15, 2902-2905; (b) Castelló, L. M.; Nájera, C.; Sansano, J. M.; Larrañaga, O.; de Cózar, A.; Cossío, F. P. Adv. Synth. Catal. 2014, 356, 38613870; (c) Castelló, L. M.; Nájera, C.; Sansano J. M.; Larrañaga, O.; de Cózar, A.; Cossío, F. P. Synthesis 2015, 47, 934-943.

[27] The initial 96:4 dr was transformed in a >99:1 dr after column chromatography purification followed by recrystallization in hexane/ethyl acetate maintaining the $>99: 1 \mathrm{er}$.

[28] Study of minimum energy calculations using molecular mechanic method MM2 in ChemBio3D program. 